

\title{
Perceived Fairness in the Taxation of a Digital Business Model
}

\author{
Stefan Greil ${ }^{\mathrm{a}}$, Christian Schwarz ${ }^{\mathrm{b}}$, Stefan Stein ${ }^{\mathrm{c}}$
}

\begin{abstract}
The "fair" taxation of digital business models is challenging. One of the key aspects - both policy makers and the public opinion consider as most pressuring - is the determination of intragroup transfer prices for intangibles used in digital business models. In this paper, we address the issue of a "perceived fair" taxation of the digital economy in the light of the arm's length principle based on a survey with transfer pricing experts. The aim of the survey is not to estimate arm's length profit allocations but rather to elicit fairness considerations in different transfer pricing related scenarios.

In a digital economy framework where arm's length profits are distributed extremely inequitably, subjects perceive this distribution of profits as most unfair compared to more balanced scenarios. Consequently, subjects propose a "fair" distribution of profits that substantially differs from the exogenously given arm's length allocation. In scenarios with a more balanced arm's length allocation of profits, we find that the perceived fairness for the expert groups increases while a control group of business students is almost not influenced by the arm's length allocation of profits.
\end{abstract}

JEL Classification: D90, F23, H25, H26, K34

Keywords: corporate income tax; profit-shifting; arm's length principle; fairness; digital economy

a University of Hamburg, Post-Doctoral fellow, Mittelweg 177, stefangreil@gmx.net

b Corresponding author: Hochschule Duesseldorf, Professor for Empirical Economics,

Muensterstr. 156, 40476 Düsseldorf, christian.schwarz@hs-duesseldorf.de

c Quantum Steuerberatungsgesellschaft mbH, Magirusstr. 35/2, 89077 Ulm, stefan.stein@quantum-tax.de 


\section{Introduction}

Almost all articles, press-releases or political statements dealing with the taxation of digital business models in principle and the international allocation of taxing rights across jurisdictions postulate that the digital economy must be "fairly" taxed. At the same time the OECD base erosion and profit shifting (BEPS) reports and the current transfer pricing regulations state that digital business model should to be taxed where value is created and the business activity takes place ${ }^{1}$. In the past, evidence showed that a "perceived fair" taxation was not sufficiently secured since especially digital business models were quite successful in avoiding taxation. ${ }^{2}$ For example, the European Union estimates that companies with digital business models pay on average half the effective tax rate of companies with traditional business models. ${ }^{3}$ Therefore, the EU Commission (COM) calls for "fair" taxes. One will find the word "fair" in the communication on 'A Fair and Efficient Tax System in the European Union for the Digital Single Market' eighteen times without describing or explaining what can be understood as "fair". ${ }^{4}$ On the contrary, it has been extensively documented in the international tax literature that value creation in general is also very difficult and no common or concise definition currently exists for this concept. ${ }^{5}$

In traditional business models the taxation rights of a jurisdiction correspond with the scope and extent of the multinational enterprises (MNE's) business activities in the country. However, in digital business models digital goods and services can be provided without a physical presence in specific county. Therefore, it is not decisive to have a physical presence in a certain country and, therefore, the value creation is more difficult to evaluate since typical heuristics such as employees or tangible assets as reference points are not available or reasonable. ${ }^{6}$ The main concern of the fairness debate is that "user" value creation due to data gathering is located in a tax jurisdiction where the company carrying out a digital activity is not physically established and where its activities thus cannot be taxed. In this context transfer pricing regulations are of high importance since cross-border intragroup transactions within related entities have to be determined according to the arm's length principle ("ALP"). The ALP is legally based in national tax law and in double tax treaties (Article 9 OECD-Model Tax Convention). Its main purpose is to ensure profits to be taxed where they have been economically generated; transfer pricing outcomes should be aligned with economic value creation. Thus, the determination of transfer prices is required by tax authorities to allocate the taxable income between the different countries' taxation. A transfer price is deemed arm's length if it is equal to the price at which two independent parties would trade.

C.f. OECD (2018), Interim report Task Force Digital Economy, Chapter 1, Para 12.

Typical channels include transfer pricing (Davies et al., 2018), debt shifting (Egger et al., 2014), royalties (Dischinger and Riedel, 2011; Karkinsky and Riedel, 2012; Griffith et al., 2014) and shifting of functions (Mutti and Grubert, 2004; Voget, 2011; Ruf and Weichenrieder, 2012).

C.f. EU Commission Expert Group on Taxation of the Digital Economy, 28.05.2014.

4 The COM published two proposals: "Proposal for a Council Directive laying down rules relating to the corporate taxation of a significant digital presence" and "on the common system of a digital services tax on revenues resulting from the provision of certain digital services".

C.f. Olbert and Spengel (2017).

6 See also BEPS Action Point 1 where is argued that digitalization facilitates the internationalization of all aspects of a company's business as it is not necessary to create a physical local.

Forschungsberichte des Fachbereichs Wirtschaftswissenschaften der Hochschule Düsseldorf Ausgabe 47 (2018) ISSN: 2365-3361

URN: urn: nbn: de: hbz: due62-opus-15759

URL: https://opus4.kobv.de/opus4-hs-duesseldorf/1575

DOI : $10.20385 / 2365-3361 / 2018.47$ 
In practice, complex transfer pricing guidelines and rules often do not provide a satisfactory solution for tax authorities, see Devereux and Vella (2017). The current transfer pricing system which focuses on value creation and business activities (i.e. functions performed, risks borne and assets employed) can be used to structure the tax burden of an MNE-group. It even provides the incentive to structure the tax burden and can also have negative welfare effects (Devereux and Keuschnigg, 2008; Luckhaupt et al., 2012; Durst, 2012; Morse, 2013; Aliber, 1993; Vann, 2010; Rectenwald, 2012; AviYonah et al. 2009). Holzmann (2017), for instance, determines that transfer pricing that involves intellectual property (IP) - which is of high importance in the digital economy - becomes a source for base erosion in the second half of the decade due to unobservable arm's length prices in case of IP. In the public and among tax authorities there exists currently a strong gut feeling that there could be a mismatch between where taxation of the profit takes place and where value is created especially for certain digital activities. In particular for digital business models that focus on business-to-consumer services, users's data are considered as an important element necessary for value creation. Only the interplay of users's data together with algorithms allows for value creation in such digital business models, see Brauner and Pistone (2018). Therefore, some countries are unsatisfied with the ALP and implement special levies; for example, India introduced an "equalization levy", the UK and Australia introduced "Diverted Profits Taxes" and the US the "BEAT".

In this paper, we try to address the issue of a "perceived fair" taxation in the light of the arm's length principle. The aim of our survey is neither to estimate arm's length profit allocations nor an attempt to obtain a definition of "fairness" but rather to elicit fairness considerations in transfer pricing related scenarios. Participants (tax auditors, tax advisors and business students) were presented a stylized description of digital business model in a two-country context. In principle, participants had to assess as a neutral third party if a presented arm's length allocation of profits between the countries can be considered as a "fair allocation" and what the proposed "fair allocation" of profits would be. In follow up questions, we also vary the tax differential in our simplified two-country framing. We analyze our survey along the following guiding research questions:

- Research Question 1: Do expert groups (i.e. tax auditors and tax advisors) follow the exogenously given arm's length allocation of profits and propose as a "fair" allocation of profits the arm's length allocation? Does the control group of business students as non-experts deviate in their proposed "fair" allocation from the arm's length allocation?

- Research Question 2: Is the proposed "fair" allocation of profits dependent on the tax rates?

- Research Question 3: Do expert groups consider the exogenously given arm's length allocation of profits as "fair"? Does the control group of business students consider the arm's length allocation as "fair"?

- Research Question 4: Is the "perceived fairness" dependent on the tax rates? 
In a scenario where arm's length profits are distributed extremely inequitably $(100 \%$ versus $0 \%$ with no taxation in one county), all groups perceive this distribution of profits as "unfair". In relative terms, most "unfair" compared to more balanced scenarios. Consequently, all groups propose as "fair" profit split and distribution of profits that substantially differs from the exogenously given arm's length allocation. In scenarios with more balanced arm's length allocation of profits, we find that the "perceived fairness" for the expert groups increases while business students are almost not influenced by the arm's length allocation of profits. Therefore, the exogenously given arm's length allocation works as a "fairness" anchoring for experts. Independent of this anchoring, also in more balanced scenarios we find that experts propose as a "fair" profit split an allocation that can substantially differ from the stated arm's length allocation. Quite different, our control group of business students consider the most balanced allocation as the comparable most "fair" allocation of profits and are not influenced by the arm's length allocation of profits.

In the light of our research questions 1 and 3, we find that expert groups are anchored by the arm's length allocation both in terms of "perceived fairness" as well as proposed "fair" profit allocations. However, the proposed "fair" profit allocation can substantially differ from the stated arm's length allocation. We find that our control group is not influenced by the arm's length allocation and therefore often considers this allocation as relatively more "unfair" compared to experts. Related to our research questions 2 and 4 , we find that tax rates do not have an impact on the "perceived fairness" for both experts and our control group. A complementary per-subject analysis shows that especially within the expert groups, heterogeneity in "fairness" considerations is high. We find that some tax advisors consider all three scenarios as more or less equal "fair" and therefore closely follow the arm's length allocation. In contrast, tax auditors are highly represented in another cluster of subjects which clearly prefer are more equal distribution of profits.

To the best of our knowledge we are the first who have conducted a survey allowing to disentangle the difference between an arm's length and perceived as well as proposed "fair" allocation of profits. In doing so, we focus on tax auditors and their fairness considerations compared to other groups involved in international taxation such as tax advisors. Related to this, we contribute to the current research in a threefold way: The results can have an impact on the current political discussions and could pave the way for further related experimental research regarding the "perceived fairness" of transfer pricing. In addition, our results also provide insights for corporate tax payers which want to avoid a reputation for "unfairness" due to very aggressive tax structuring and rather want to show moral leadership, see Gribnau and Jallai (2017). In non-tax frameworks Kahneman et al. (1986a,b) and following papers show that even profit-maximizing firms to act "fair" if "unfair" behavior involves e.g. punishment costs. Furthermore, we provide insights regarding the fairness consideration of tax auditors which could be anticipated by taxpayers. 


\section{Related Literature}

A vast literature shows that individuals dislike perceived inequitable outcomes and have some form of social preference. The ultimatum game (see Güth et al, 1982) is the prototypical game to test whether individuals care not only about their own payoffs, but also about their payoffs relative to those of others. From a standard economic point of view the profit-maximizing proposer should walk off with virtually the whole surplus in the bilateral bargaining game. However, it is well-known that this is generally not the case because individuals have some form social preferences. In particular, responders resist unfair offers (Güth et al., 1982; Güth and Tietz, 1990; Roth, 1995) and proposers make fair offers instead of using their strategic advantage. A robust result in these games is that offers of less than $20 \%$ to the responder are often rejected, whereas offers of $40 \%$ or more are usually accepted (Camerer, 2003; Fehr and Schmidt, 2003; Roth, 1995; Seldon and Tsigaris, 2010). The simplicity of the ultimatum game renders the 50/50 split a fair outcome (at least in Western cultures; Fehr et al., 2009 with examples). For our subject group of tax experts, empirical evidence shows that the actual agents involved in the international taxation rights, e.g. tax auditors, do judge the outcomes based on "fairness" considerations. Among others, Kirchler et al. (2003) find that fiscal officers are strongly affected by social preferences. Compared to various other groups such as business students, business lawyers or entrepreneurs, the authors find that tax auditors judge all forms of tax reduction as least fair. Following Kirchler et al. (2003) we focus on fiscal officers compared to other groups involved in (international) taxation such as tax advisors. Our subject pool includes two "expert" groups as well as a control group of business students.

In our survey participants are in the position of a neutral third party. Therefore, also the literature on distributive fairness norms, besides social preferences as a proposer or responder, is closely related. Even if marginal productivities of participants in a collaboration are clearly observable (as it is the case in our survey since the arm's length allocation of profits is exogenously given), the importance of distributive fairness norms is highly context-dependent (see Karagözoğlu (2012) for a survey). ${ }^{7}$ Furthermore, as argued in the introduction and is especially true for digital business model, value contributions (i.e. marginal contributions) are extremely difficult to verify. In such cases, the collaboration partners are frequently remunerated by means of a pre-defined fixed share of the joint output (i.e. by implementing some kind of "profit sharing"). In our survey, we account for to this by focusing "only" on the profit shares and not on the concrete transfer pricing method. In such scenarios, equal sharing is often referred to as a normatively appealing allocation rule (see Ashlagi et al. (2012)).

Furthermore, in the more tax evasion related literature it is found that "perceived fairness" has an impact on the attitude and behavior of taxpayers. For instance, the level of tax evasion decreases if the tax system is perceived as fair by the taxpayers (see, for example Fortin et al., 2007; Spicer and Becker, 1980; Kornhauser, 2005). Conversely,

Karagözoğlu (2012) shows that the prevalence of different fairness norms depends inter alia on the type of inputs. For financials investments the majority of subjects prefers equal shares (see, e.g., Gantner et al. (2001) or Cappelen et al. (2007)) while for real-effort tasks the evidence is less supportive of equal sharing (see, e.g., Konow (2000) or Cappelen et al. (2010)).

Forschungsberichte des Fachbereichs Wirtschaftswissenschaften der Hochschule Düsseldorf Ausgabe 47 (2018) ISSN: 2365-3361

URN: urn:nbn: de: hbz: due62-opus- 15759

URL: https://opus4.kobv.de/opus4-hs-duesseldorf/1575

DOI : $10.20385 / 2365-3361 / 2018.47$ 
taxpayers may evade because the tax system is unfair and the more they received social information on the extent of tax evasion by others the less they felt guilty to do so and evasion increased. Thus, an individual will comply as long as she or he believes that compliance is the social norm (however defined); conversely, if non-compliance becomes pervasive, then the social norm of compliance disappears (Elster, 1989; Alm, 2013).

\section{Survey}

\section{A. Participants}

The questionnaires were distributed to tax auditors, tax advisors as well as business students in Germany. The respondents were approached in conferences or seminars (tax auditors and tax advisors) or within university seminars (business students). The group of tax auditors and tax advisors were specifically addressed in transfer pricing related conferences and seminars. Therefore, they showed either practical or theoretical experience or at least a very high affinity to transfer pricing related topics since they have background in international tax. The response rate in this set-up was high and nonresponse occurred rarely. Overall, 115 subjects, 76 men and 36 women ( 3 not known) participated. The following Table 1 summarizes the subject sample. Relevance refers to the questions whether digital business models are becoming, subject to the individual judgement, more important in the future. Experience summarizes the personal experience in the valuation of transfer pricing issues for digital business model. In the following we consider a transfer pricing related subject in our survey design. Therefore, we consider tax auditors and tax advisors as "experts" and business students as a control group.

\begin{tabular}{|l|c|c|c|c|}
\hline Subject pool & Total & Auditors & Advisors & Students \\
\hline Size & 115 & 48 & 36 & 31 \\
\hline Age $($ mean $)$ & 37.6 & 43.3 & 42.6 & 23.6 \\
\hline Relevance $=$ yes & $99 \%$ & $100 \%$ & $100 \%$ & $97 \%$ \\
\hline Experience $=$ yes & $43 \%$ & $46 \%$ & $28 \%$ & $13 \%$ \\
\hline
\end{tabular}

Table 1: Subject Pool Descriptive

\section{B. Experimental Design}

In the questionnaire, participants were presented a description of a stylized digital business model in a stylized two-country world: A firm develops an algorithm for a social network in country A. Users participate in the social network and enable the firm to generate revenue and profits with the submitted user data. Besides country A, the social network is also active in country B. For simplicity, both countries "supply" the same number of participants in the social network and the tax rates are identical and set to $20 \%$. 
Participants were asked to assess as a neutral third party if a presented allocation of profits between the countries can be considered as a "fair allocation" and what the "fair allocation" would be. We asked first: "Do you consider the presented allocation of profits between country A and country B as a fair allocation?". Afterwards we asked in a second question: "What do you consider as a fair allocation of profits between country A and country B". Participants were asked to answer question 1 on scale from 1 to 9 (1= not fair to 9 = fair). For the second question predefined allocations of the normalized (total) profit of $100 \mathrm{mEUR}$ were presented. It is crucial to note that both questions do not refer to an arm's length allocation of profits but rather "perceived fair" allocations. The aim of the survey is not to estimate arm's length profit allocations but rather to elicit "fairness" considerations in transfer pricing related scenarios.

In total, participants were presented three scenarios that varied the taxation right and the respective proposed/presented allocation in each questionnaire. In Scenario 1, no taxation right was given to country $\mathrm{B}$ in principle such that all profits are taxed in country A (100/0 allocation between A and B). In Scenario 2, country B captures a taxation right since (routine) marketing activities for country B are performed in country B. It is now stated in the questionnaire that an established transfer pricing method results in an allocation of 90 mEUR for country A and 10 mEUR for country B (90/10 allocation between A and B). In a final Scenario 3, we increased the profit allocation to country B such that the relative profit allocation is $60 \mathrm{mEUR}$ for country A and $40 \mathrm{mEUR}$ for country B (60/40 allocation between A and B). It was our intention to set the stated profit allocation as the exogenously given arm's length allocation of profits. Therefore, in Scenario 2 and 3 we stated that an "established transfer pricing method" resulted in the given allocation. In Scenario 1, the allocation of profits is, by definition of the questionnaire, arm's length since no taxation rights in principle are given to country B. We deliberately did not give specific information regarding the applied transfer pricing method in order to avoid doubts regarding the appropriateness of the method. We use our two questions approach (perceived fairness and proposed fair allocation) in all three scenarios. We vary each scenario by assuming that country A is a low tax country and reduce the tax rate from $20 \%$ to $5 \%$.

\section{Results}

\section{A. Results: Proposed Fair Allocation}

We first focus on the research questions 1 and 2 which ask for the proposed "fair" allocation. In Scenario 1, the arm's length allocation of profits is 100/0 between country A and country B. We clearly observe that all three group deviate in their "fairness" considerations from this arm's length allocation of profits by proposing a "fair" allocation of profits significantly different from 100/0 ( $\mathrm{p}<0.01$ Wilcoxon Signed-rank (WSR) test for all groups). In economic terms, the difference is quite substantial. Notably, both expert groups propose $75 / 25$ and 78/22 as their mean "fair" allocation while the proposed "fair" allocation for the control group is significantly even more equal ( $\mathrm{p}<0.01$ WSR test pairwise).

Forschungsberichte des Fachbereichs Wirtschaftswissenschaften der Hochschule Düsseldorf Ausgabe 47 (2018)

ISSN: 2365-3361

URN: urn:nbn: de: hbz: due62-opus- 15759

URL: https://opus4.kobv.de/opus4-hs-duesseldorf/1575

DOI : $10.20385 / 2365-3361 / 2018.47$ 
The falling apart between the "perceived fair" and arm's length allocation is also apparent in Scenario 2 ( $\mathrm{p}<0.01$ WSR for all groups). The arm's length allocation of profits as presented in the questionnaire has almost no impact on the proposed "fair" allocation of the expert groups (change from $100 / 0$ to $90 / 10$, only $\mathrm{p}<0.10$ for tax advisors and not significant for tax auditors). The expert groups only weakly reduce the 75/25 and 78/22 allocation to a more equal distribution of 74/26. That pattern is different in Scenario 3 in which both expert groups adapt their proposed "fair" allocation to the presented arm's length allocation of profits (change from 90/10 to 60/40, $p<0.01$ for tax advisors and for tax auditors). On the contrary, the control group is again not influenced by the arm's length allocation of profits.

This difference between experts and our control group is also highlighted in the subject pool comparison within scenarios, where we find significant difference between the experts and the control group, but not between the experts (in 100/0 and 90/10, $\mathrm{p}<0.01$ for tax advisors and tax auditors, in $60 / 40 \mathrm{p}<0.10$ for tax advisors, $\mathrm{p}<0.05$ for tax auditors, Mann-Whitney-U (MWU) test). Finally, only in the last Scenario 3 which almost equally allocates profits across country $\mathrm{A}$ and $\mathrm{B}$ we find differences between the arm's length and proposed "fair" allocation of profits for the experts $(\mathrm{p}<0.05$ for tax advisors, $\mathrm{p}<0.01$ for tax auditors, MWU test) but not for the student control group. Our results are illustrated in Figure 1. Given our research question 1 as stated in the introduction, we find mixed results. Expert groups are anchored by the arm's length allocation of profits, but they do not follow closely. In contrast, the control group is not influenced by the arm's length allocation. We summarize in:

Result 1 - Proposed Fair Allocation of Profits: The proposed fair and arm's length allocation of profits significantly differ if presented profits allocations are unequally distributed (Scenario 1 and 2 with 100/0 and 90/10). This not only holds for the student control group but also for the expert groups. The presented arm's length allocation of profits impacts the expert groups allocation if profits are more equally balanced, while the control group is almost not influenced by the arm's length allocation of profits.
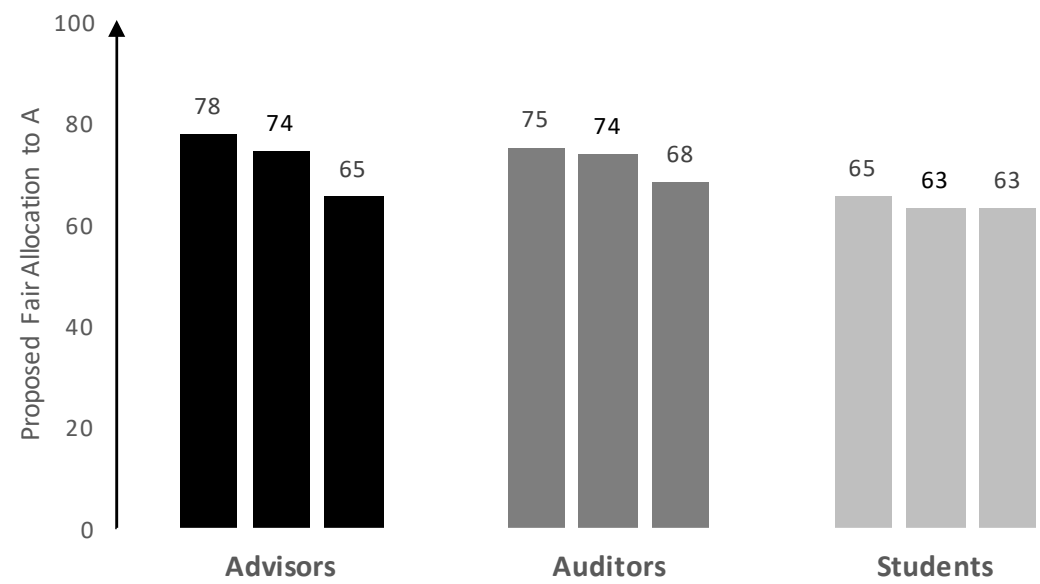

Figure 1: Proposed Fair Allocation across Subject Pools and Scenarios 
We now study the effect of a tax differential as stated in research question 2. For all groups and all scenarios, we do not find a significant effect on the proposed "fair" allocation of profits:

Result 2 - Proposed Fair Allocation of Profits and Tax Rates: For all groups and all scenarios, we do not find a significant effect of the tax rates on the proposed fair allocation of profits.

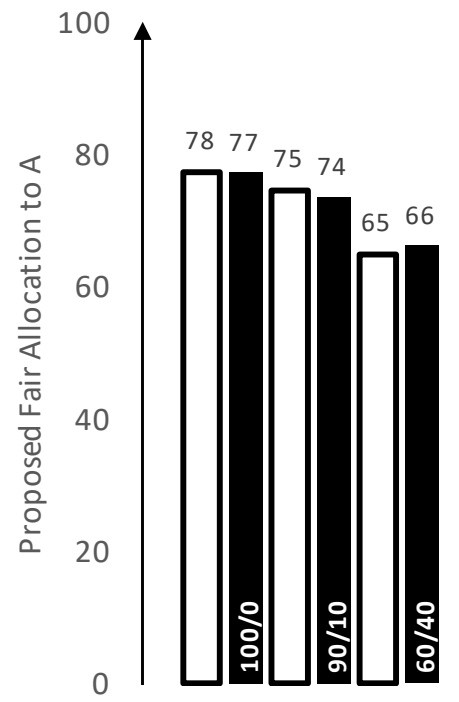

Advisors

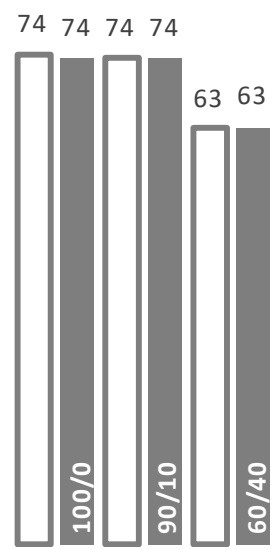

Auditors

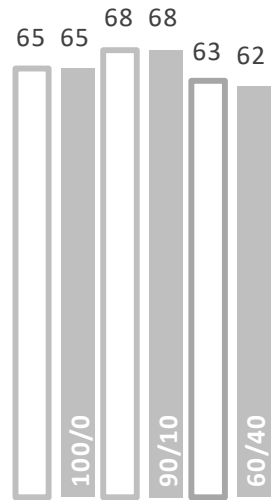

Students

Figure 2: Proposed Fair Allocation across Subject Pools and Scenarios - Tax Differential

\section{B. "Perceived Fairness" of an Arm's Length Allocation}

We continue with the analysis of the question regarding the "perceived fairness" of the stated profit allocation and research questions 3 and 4 . Compared to tax advisors, tax auditors perceive the 100/0 profit allocation significantly more "unfair" ( $p<0.05$ MWU test). However, comparing the fairness perception in the 100/0 scenario with the 90/10 scenario shows a significant increase in "perceived fairness" for both expert groups (5.4 to $6.1 \mathrm{p}<0.10$ and 4.0 to $5.5 \mathrm{p}<0.01 \mathrm{WSR}$ test). The increase in "fairness" is especially strong and significant for tax advisors. In contrast to the previous Scenario 1, both expert groups perceive the fairness in Scenario 2 now as equally "fair" or "unfair" (not significantly, MWU test). Increasing the tax base for country B further in Scenario 3 yields again an increase in "perceived fairness" for both expert groups (6.1 to 7.3, $\mathrm{p}<0.10$ for auditors and significant for advisors, 5.5 to $6.5, \mathrm{p}<0.05$, WSR test). Again, we only find a weak difference between both subject groups ( 7.3 vs. $6.5, \mathrm{p}<0.10 \mathrm{MWU}$ test). These results regarding the "perceived fairness" are different compared to the proposed "fair" allocation of experts as presented in the previous section. Regarding the 
"perceived fairness", experts can differ while the proposed fair allocation is not different (e.g. in Scenario 1)

Regarding our control group, we find no significant difference in the subject pools in the $100 / 0$ scenario to tax auditors but compared to tax advisors (5.4 vs. $4.0 \mathrm{p}<0.10 \mathrm{MWU}$ test). Like tax auditors, allocating a small profit share to country B increases the "perceived fairness" (weak) significantly (4.0 to $4.8 \mathrm{p}<0.10 \mathrm{WSR}$ test). Only a further increase to $60 / 40$ in Scenario 3 yields a strong increase ( $<<0.01$ MWU test) such that all the control group pairwise to the experts perceive 60/40 as equally "(un-)fair" (MWU test, pairwise). These findings mirror the proposed "fairness" results of the control group as presented in the previous section, i.e. this group perceives most "fair" and proposes this as the "fair" allocation the $60 / 40$ Scenario 3.

Given our research question 3 as stated in the introduction, we find that expert groups do not necessarily consider the exogenously given arm's length allocation of profits as "fair". Albeit in the extreme scenario tax advisors and tax auditors differ in the "perceived fairness" of the extreme scenario, the "perceived fairness" of experts is more closely aligned compared to the control group. Similar to Result 1, experts are also anchored by the arm's length allocation in the "perceived fairness" while the control group is not. We summarize in:

Result 3 - Perceived Fairness: Compared to tax advisors, tax auditors perceive the 100/0 profit allocation significantly more unfair. However, a small allocation of profits for country B significantly increase the perceived fairness for experts. A more equal allocation of profits (60/40 in Scenario 3) increases the perceived fairness for both experts, but the effect is economically small. This is different compared to our control group of business students which consider $60 / 40$ as the comparable most fair allocation of profits.

For our expert groups, the "perceived fairness" is independent of the tax rates (no significant differences MWU). Compared to the expert groups, our control group only considers differences in the tax rates as important if the taxation rights are balanced (7.0 to $6.2 \mathrm{p}<0.01 \mathrm{WSR}$ test in the last Scenario 3). Except the last finding these observations mirror the proposed "fairness" results as presented in the previous section. Our Results 3 and 4 are illustrated in Figure 3.

Result 4 - Perceived Fairness and Tax Rates: For expert groups in all scenarios, we do not find a significant effect of the tax rates on the perceived fair allocation of profits. For our control group, this also holds with exception of the last scenario.

Summarizing Results 1-4, we observe that significant differences between expert groups exist (e.g. in the "perceived fairness" of the 100/0 scenario). In aggregate, both expert groups are comparable in the sense that they jointly deviate from the exogenously given arm's length allocation of profits in their proposition of a "fair" allocation of profits. However, the arm's length allocation anchors the expert groups for their proposed "fair" distribution. These results show that that the experts try to align "fairness" considerations and the arm's length principle and do not necessarily prefer "pure" equal sharing. This observation is related to the experimental evidence on distributions norms with realeffort tasks which shows that observable productivities are, albeit not perfectly, reflected in the distribution of profits of joint production, see Karagözoğlu (2012). In our survey 
productivities are clearly observable (for experts) since the exogenous allocation of profits reflects value contributions in the transfer pricing methodology status quo. In contrast, the control group of business students clearly prefer equal shares similar to the evidence as provided by Gantner et al. (2001) or Cappelen et al. (2010). Our control group either does not observe the marginal contributions or considers the investment in the algorithm as a financial investment. The experimental evidence by Gantner et al. (2001) or Cappelen et al. (2007) suggests that compared to real-effort tasks, pure financial investments tend to increase the preference of equal sharing.

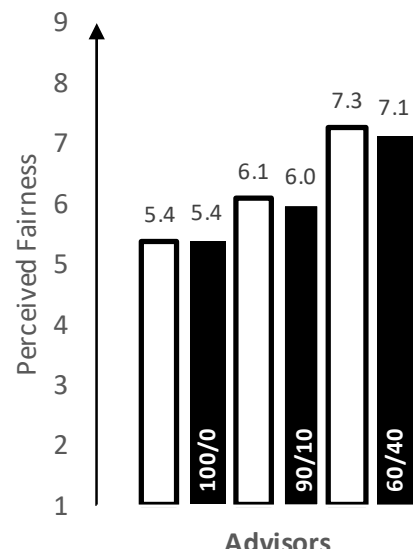

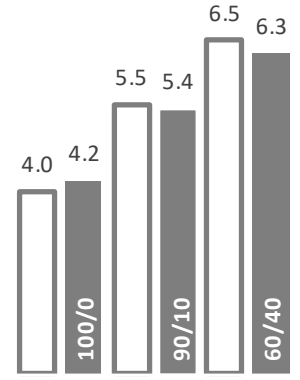

Auditors

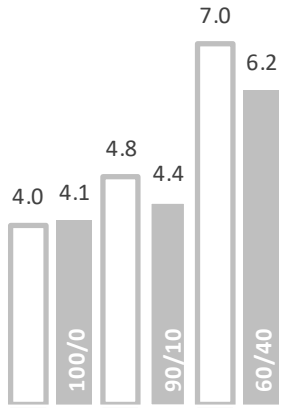

Students

Figure 3: Perceived Fairness across Subject Pools and Scenarios - with Tax Differential

\section{Robustness Checks}

The heterogeneity within all groups regarding their perceived as well as proposed "fair" allocation is high. The following Table 2 illustrates this heterogeneity for Scenario 1, both in terms of "perceived fairness" as well as proposed "fair" allocation.

\begin{tabular}{|l|c|c|c|c|c|c|}
\hline Statistic & \multicolumn{2}{|c|}{ Auditors } & \multicolumn{2}{c|}{ Advisors } & \multicolumn{2}{c|}{ Students } \\
\hline & Fairness & Allocation & Allocation & Fairness & Allocation & Fairness \\
\hline 3. Quartile & 6.5 & 80 & 8.0 & 100 & 6.0 & 70 \\
\hline Mean & 4.0 & 75 & 5.4 & 78 & 4.0 & 65 \\
\hline Median & 3.0 & 70 & 6.0 & 75 & 3.0 & 70 \\
\hline 1. Quartile & 2.0 & 70 & 3.0 & 65 & 2.0 & 50 \\
\hline
\end{tabular}

Table 2: Cluster Analysis 
This great heterogeneity motivates that within each subject pool further characteristics such as risk preferences should be analyzed. Therefore, we conducted a cluster analysis (k-means) based on the three "perceived fairness" observations from the three scenarios. The following Table 3 shows the average "perceived fairness" as we all proposed "fair" allocation across clusters. All cluster show a substantial sample size and the elbow rule indicates that $\mathrm{k}=3$ is optimal. Table 4 shows the relative prevalence of the three clusters across subject groups.

\begin{tabular}{|c|c|c|c|c|c|c|c|}
\hline \multicolumn{2}{|c|}{} & \multicolumn{3}{c|}{ Perceived Fairness } & \multicolumn{3}{c|}{ Proposed Fair Allocation for A } \\
\hline Cluster & Subjects & $100 / 0$ & $90 / 10$ & $60 / 40$ & $100 / 0$ & $90 / 10$ & $60 / 40$ \\
\hline 1 & 36 & 6.6 & 7.3 & 8.3 & 79.7 & 77.2 & 64.2 \\
\hline 2 & 55 & 2.4 & 3.3 & 7.1 & 66.7 & 63.6 & 61.1 \\
\hline 3 & 24 & 5.8 & 7.8 & 4.3 & 77.5 & 79.2 & 78.3 \\
\hline
\end{tabular}

Table 3: Cluster Analysis

We interpret Cluster 1 as a group of subjects that monotonically perceive a more equal distribution of profits as more "fair" compared to more unequal distributions. This is also reflected in the highest "perceived fairness" in Scenario 3. Cluster 2 can be interpreted as subjects that perceive an extreme Scenario 1 with no taxation rights as "unfair" and also consider only small increases in the profit allocation to country B as comparable "unfair". These subjects only consider Scenario 3 with the most equal distribution as "fair". Subjects in Cluster 3 already perceive the Scenario 1 as relatively "fair" and perceive the middle Scenario 2 as the most "fair" allocation of profits. These subjects seem to consider the algorithm as an important value driver since a more equal distribution of profits reduces the "perceived fairness". Controlling for personal characteristics within clusters we do not find significant differences in personal characteristics such as gender, experience with digital business models, age, and risk aversion.

\begin{tabular}{|c|c|c|c|}
\hline Cluster & Advisors & Auditors & Students \\
\hline 1 & $50.0 \%$ & $18.8 \%$ & $29.0 \%$ \\
\hline 2 & $39.9 \%$ & $50.0 \%$ & $54.8 \%$ \\
\hline 3 & $10.1 \%$ & $31.3 \%$ & $16.1 \%$ \\
\hline
\end{tabular}

Table 4: Clusters across Subjects Pools

Table 4 shows the distribution of clusters separated by subject pools. As already highlighted, heterogeneity across clusters is large for all three subject pools. However, $50 \%$ of all advisors can be sorted into the Cluster 1, a group of subjects that are influenced by "fairness" considerations and most closely follow the arm's length allocation of profits in their proposed "fair" allocation (the share for A monotonically decreases from 79.7 to 77.2. to 64.2). Within the tax advisors also a large group of subjects consider Scenario 3 with the most equal distribution as "fair" (Cluster 2). For tax auditors, the minority of subjects are in Cluster 1 and "directly" follow the arm's 
length allocation. ${ }^{8}$ In contrast, $50 \%$ of all tax auditors belong to Cluster 2 which prefer the most equal distribution. Also, a large group perceives the middle Scenario 2 as, balancing both the value of user as well as the algorithm.

Result 5 - Cluster Analysis: A cluster analysis indicates that all subject pools show great heterogeneity in their perceived fairness. However, identifying clusters also shows that advisors consider all three scenarios as more or less equal fair and therefore closely follow the arm's length allocation. In strong contrast, auditors are highly represented in another cluster of subjects which prefer only are more equal distribution of profits. Our control group also shows a tendency to prefer a more equal distribution of profits based on their fairness considerations.

Finally, we use an ordinary least squares regression approach to control for personal characteristics on a per-subject level. We use the proposed "fair" allocation as well as "perceived fairness" in all three scenarios as the depended variable and personal characteristics (gender, experience with digital business models, age, risk aversion) as well as group dummies as explanatory variables. Besides the effects of the group already discussed previously we do not find any further statistically significant effects on a persubject level.

\section{Conclusion}

In this paper, we address the issue of a "perceived fair" taxation in the light of the arm's length principle based on a survey with transfer pricing experts. The aim of the survey is not to estimate arm's length profit allocations but rather to elicit fairness considerations in transfer pricing related scenarios. In a digital economy framework where arm's length profits are distributed extremely inequitably, subjects perceive this distribution of profits as most unfair compared to more balanced scenarios. Consequently, subjects propose a "fair" distribution of profits that substantially differs from the exogenously given arm's length allocation. In scenarios with a more balanced arm's length allocation of profits, we find that the perceived fairness for the expert groups increases while a control group of business students is almost not influenced by the arm's length allocation of profits. Fairness consideration play an important role in the current public discussion regarding the "fair" taxation of digital business models and therefore more experimental research is needed to understand these fairness considerations. Our paper is therefore a first attempt to understand these fairness considerations in the context of transfer pricing and digital business models.

C.f. Greil/Schwarz/Stein (2018) for a theoretical model of international taxation which assumes that tax prefer more equal distributions of taxation rights. 


\section{Literature}

Aliber, R.Z. (1993). Transfer Pricing: A taxonomy of impacts on economic welfare, in: Transnational Corporations and Regional Economic Integration, Robson, P. (Editor).

Alm, J. (2013). Expanding the Theory of Tax Compliance from Individual to Group Motivations. Tulane University Working Paper 1309.

Ashlagi, I.; Karagözoğlu, E.; Klaus, B. (2012). A non-cooperative support for equal division in estate division problems. Mathematical Social Science, 63(3), pp. 228-33.

Avi-Yonah, R.; Clausing, K.; Durst, M. (2009). Allocating Business Profits for Tax Purposes: A Proposal to Adopt a Formulary Profit Split, Florida Tax Review 9(5), pp. 497-553.

Bucovetsky, S.; Haufler, A. (2008). Tax competition when firms choose their organizational form: Should tax loopholes for multinationals be closed? Journal of International Economics, 74(1), pp. 188-201.

Brauner, Y.; Pistone, P. (2018). Some Comments on the Attribution of Profits to the Digital Permanent Establishment. Bulletin for International Taxation, 72(4a).

Camerer, C. (2003). Behavioral Game Theory. Princeton, NJ: Princeton Univ. Press.

Gantner, A.; Kerschbamer, R.; Güth, W.; Königstein, M. (2001). Equitable choices in bargaining games with joint production. Journal of Economic Behavior and Organization, 46(2), pp. 209-25.

Cappelen, A. W.; Hole, A. D.; Sørensen, E. O.; Tungodden, B. (2007). The pluralism of fairness ideals: an experimental approach. American Economic Review, 97(3), pp. 818-27.

Cappelen, A. W.; Sørensen, E. O; Tungodden, B. (2010). Responsibility for what? Fairness and individual responsibility. European Economic Review, 54(3), pp. $429-41$.

Davies, R. B.; Martin, J.; Parenti, M.; Toubal, F. (2018). Knocking on Tax Haven's Door. Multinational Firms and Transfer Pricing. The Review of Economics and Statistics, 100 (1), pp. 120-134.

Devereux, M.P.; Keuschnigg, C. (2008). The Distorting Arm's Length Principle in International Transfer Pricing. CEPR Discussion Paper No 7375.

Devereux, M.P.; Vella, J. (2017). Implications of Digitalization for International Corporate Tax Reform. Oxford University Centre for Business Taxation, Saïd Business School Working Papers. Oxford.

Dischinger, M.; Riedel, N. (2011). Corporate Taxes and the Location of Intangible Assets within Multinational Firms. Journal of Public Economics 95 (7-8), pp. 691-707. 
Durst, M. C. (2012). OECD Guidelines: Causes and Consequences, in: Fundamentals of International Transfer Pricing in Law and Economics, Springer, Berlin 2012.

Egger, P., Keuschnigg, C.; Merlo, V.; Wamser, G. (2014). Corporate Taxes and Internal Borrowing within Multinational Firms. American Economic Journal: Economic Policy 6 (2), pp. 54-93.

Elster, J. (1989). The Cement of Society - A Study of Social Order. Cambridge, UK: Cambridge University Press.

EU Commission Expert Group on Taxation of the Digital Economy. (2014). Report of the Commission Expert Group on Taxation of the Digital Economy, https:/ec.europa.eu/taxation_customs/sites/taxation/files/resources/documents /taxation/gen_info/good_governance_matters/digital/report_digital_economy. pdf, 28/05/2014.

Fehr, E.; Goette L.; Zender, C. (2009). A Behavioral Account of the Labor Market: The Role of Fairness Concerns. Annual Review of Economics, 1, pp. 355-384.

Fehr, E.; Schmidt, K. (2003). Theories of fairness and reciprocity - evidence and economic applications. In: Advances in Economics and Econometrics, Dewatripont M.; Hansen I.; Turnovsly S. (Editors), Econometric Society Monographs, Eighth World Congress, 1(1), pp. 208 - 257.

Fortin, B.; Lacroix, G.; Villeval, M.C. (2007). Tax evasion and social interactions. Journal of Public Economics, 91(11-12), pp. 2089-2112.

Gantner, A.; Güth, W.; Königstein, M. (2001). Equitable choices in bargaining games with joint production. Journal of Economic Behavior and Organization, 46(2), pp. 209-225.

Greil, S.; Schwarz, C.; Stein, S. (2018). Fairness and the Arm's Length Principle in a Digital Economy, Available at SSRN: https://papers.ssrn.com/sol3/papers.cfm?abstract_id=3209205.

Gribnau, H.; Jallai, A.-G. (2017). Good Tax Governance: A Matter of Moral Responsibility and Transparency. Nordic Tax Journal, 1(1), pp. 70-88.

Griffith, R.; Miller, H.; O'Connell, M. (2014). Ownership of intellectual property and corporate taxation. Journal of Public Economics 112, pp. 12-23.

Güth, W.; Schmittberger, R.; Schwarze, B. (1982). An experimental analysis of ultimatum bargaining. Journal of Economic Behavior and Organization, 3(4), pp. $367-388$.

Güth, W.; Tietz, R. (1990). Ultimatum bargaining behavior-a survey and comparison of experimental results. Journal of Economic Psychology, 11(3), pp. 417-449.

Holzmann, C. (2017). Transfer pricing as tax avoidance under different legislative schemes. Available at SSRN: https://ssrn.com/abstract=3164103 or http://dx.doi.org/10.2139/ssrn.3164103. 
Kahneman, D.; Knetsch, J.L.; Thaler, R. (1986a). Fairness as a constraint on profit seeking: entitlements in the market. American Economic Review, 76, pp. 728741 .

Kahneman, D.; Knetsch, J.L.; Thaler, R. (1986b). Fairness and the Assumptions of Economics. The Journal of Business, 59(4), pp. 285-300.

Karagözoğlu, E. (2012). Bargaining games with joint production. In G. Bolton and R. Croson (Hrsg.), Oxford Handbook of Economic Conflict Resolution. New York: Oxford University Press.

Karkinsky, T.; Riedel, N. (2012). Corporate taxation and the choice of patent location within multinational firms. Journal of International Economics, 88 (1), pp. 176185.

Kirchler, E.; Maciejovsky, B.; Schneider, F. (2003). Everyday representations of tax avoidance, tax evasion, and tax flight. Do legal differences matter? Journal of Economic Psychology. 24 (4), pp. 535-553.

Konow, J. (2000). Fair shares: accountability and cognitive dissonance in allocation decisions. American Economic Review, 90(4), 1072-91.

Kornhauser, M.E. (2005). Doing the Full Monty: Will Publicizing Tax Information Increase Tax Compliance? Canadian Journal of Law and Jurisprudence, 18(1).

Luckhaupt, H.; Overesch, M.; Schreiber, U. (2012). The OECD Approach to Transfer Pricing: A Critical Assessment and Proposal. Fundamentals of International Transfer Pricing in Law and Economics, Springer, Berlin 2012.

Morse, S. C. (2013). The Transfer Pricing Regs Need a Good Edit, 40 Pepperdine Law Review, 40(5).

Mutti, J.; Grubert, H. (2004). Empirical Asymmetries in Foreign Direct Investment and Taxation. Journal of Public Economics, 62(2), pp. 337-358.

Olbert, M.; Spengel, C. (2017). International Taxation in the Digital Economy: Challenge Accepted? World Tax Journal, 9(1), pp. 3-46.

OECD, (2018), Interim Report Task Force Digital Economy, https://dx.doi.org/10.1787/9789264293083-en.

Rectenwald, G. (2012). A Proposed Framework for Resolving the Transfer Pricing Problem: Allocating the Tax Base of Multinational Entities Based on Real Economic Indicators of Benefit and Burden, Duke Journal of Comparative \& International Law, 22, pp. 425-449.

Roth, A.E. (1995). Introduction to Experimental Economics. The Handbook of Experimental Economics, ed. Kagel, J.H.; Roth, A.E.; 3-109. Princeton, NJ: Princeton Univ. Press.

Ruf, M.; Weichenrieder, A.J. (2012). The Taxation of Passive Foreign investment: lessons from German experience. Canadian Journal of Economics, 45(4), pp. $1504-1528$. 
Seldon, J.R.; Tsigaris, P. (2010). The Ultimatum Game, Distribution of Income and ReDistributive Policy. American Journal of Business Education, 3(5), pp. 39-50.

Spicer, M.W.; Becker, L.A. (1980). Fiscal inequity and tax evasion: An experimental approach. National Tax Journal, 33(2), pp. 171-175.

Vann, R.J. (2010). Taxing International Business Income: Hard Boiled Wonderland and the End of the World, World Tax Journal, 2(3), pp. 291-346.

Voget, J. (2011). Relocation of Headquarters and International Taxation. Journal of Public Economics 95 (1), pp. 1067-1081. 


\title{
Forschungsberichte des Fachbereichs Wirtschaftswissenschaften der Hochschule Düsseldorf
}

\section{Düsseldorf Working Papers in Applied Management and Economics}

ISSN 2365-3361

\section{Bisher erschienen:}

\author{
Ausgabe 47 \\ Greil, Stefan; Schwarz, Christian; Stein, Stefan: \\ Perceived Fairness in the Taxation of a Digital Business Model \\ https://opus4.kobv.de/opus4-hs-duesseldorf/1575
}

\section{Ausgabe 46}

Albers, Felicitas G. (Hrsg.):

Digitale Hochschule: Tagungsband der 93. BundesDekaneKonferenz Wirtschaftswissenschaften, 16.-18. Mai 2018, Hochschule Düsseldorf

https://opus4.kobv.de/opus4-hs-duesseldorf/1571

\section{Ausgabe 45}

Schüren-Hinkelmann, Andrea; Ziehe, Nikola:

Herausforderungen beim Pricing im Multi-Channel-Retailing: Identifikation von Lösungsansätzen unter besonderer Berücksichtigung der Nachfragersicht

https://opus4.kobv.de/opus4-hs-duesseldorf/1570

\section{Ausgabe 44}

Kalka, Regine; Abel, Katrin:

Customer Centricity: Konzeptionelle Grundlagen und Implementierung

https://opus4.kobv.de/opus4-hs-duesseldorf/1558

\section{Ausgabe 43}

Gillessen, Michelle; Khabyuk, Olexiy:

Die Digitalisierung der Außenwerbung: Eine empirische Untersuchung der innermenschlichen

Wahrnehmungsprozesse am Beispiel digitaler City-Light-Poster (DCLP)

https://opus4.kobv.de/opus4-hs-duesseldorf/1540 


\section{Ausgabe 42}

Greil, Stefan; Schwarz, Christian; Stein, Stefan:

Fairness and the Arm's Length Principle in a Digital Economy

http://fhdd.opus.hbz-nrw.de/volltexte/2018/1202/

\section{Ausgabe 41}

Khabyuk, Olexiy (Hrsg.):

Nachwuchswissenschaftliche Impulse zur Digitalisierung der Kommunikation

http://fhdd.opus.hbz-nrw.de/volltexte/2018/1185/

\section{Ausgabe 40}

Khabyuk, Olexiy; Kops, Manfred:

Broadcasting as a Means of Signal Transmission in Germany

http://fhdd.opus.hbz-nrw.de/volltexte/2018/1173/

\section{Ausgabe 39}

Steusloff, Tatjana; Krusenbaum, Lena:

Einfluss von Online-Ratings auf die Preisbereitschaft von Konsumenten am Beispiel von Amazon

http://fhdd.opus.hbz-nrw.de/volltexte/2018/1174/

\section{Ausgabe 38}

Gerhards, Claudia:

Snapchat in Deutschland: Wie verwenden Nutzer die App und was publizieren Medienmarken?

http://fhdd.opus.hbz-nrw.de/volltexte/2017/1144/

\section{Ausgabe 37}

Kalka, Regine; Telkmann, Verena; Grimmer, Thea; Daniel, Nils; Wille, Annika; Busboom, Wiebke; Amet Oglou, Meltem:

Servicequalität der Telefonhotlines von Lebensmittelherstellern

http://fhdd.opus.hbz-nrw.de/volltexte/2017/1135/

\section{Ausgabe 36}

Telkmann, Verena; Kalka, Regine:

Wirkung von Live-Chats in Online-Shops auf die Kaufentscheidung

http://fhdd.opus.hbz-nrw.de/volltexte/2017/1134/ 


\section{Ausgabe 35}

Weinert, Stephan:

Zum Zusammenhang zwischen Employer Awards und Arbeitgeberattraktivität

http://fhdd.opus.hbz-nrw.de/volltexte/2017/1067/

\section{Ausgabe 34}

Quack, Helmut:

KÖLSCH versus ALT: Erkenntnisse aus konsumentenpsychologischen Experimenten

http://fhdd.opus.hbz-nrw.de/volltexte/2016/974/

\section{Ausgabe 33}

Kalka, Regine; Bär, Greta:

Herausforderungen und Besonderheiten der Zielgruppe Silver Surfer im Hinblick auf die Gestaltung eines

Webshops

http://fhdd.opus.hbz-nrw.de/volltexte/2015/900/

\section{Ausgabe 32}

Quack, Helmut:

Der Einsatz quantitativer Methoden zur Messung der Wirkung von Kunst auf junge Menschen am Beispiel einer Skulptur von Katharina Grosse

http://fhdd.opus.hbz-nrw.de/volltexte/2015/899/

\section{Ausgabe 31}

Kalka, Regine; Schlabbers, Martina:

Konzept einer Stakeholderkommunikation in Unternehmenskrisen am Beispiel von zivilgesellschaftlichen Bewegungen bei Industrie- und Infrastrukturprojekten

http://fhdd.opus.hbz-nrw.de/volltexte/2014/877/

\section{Ausgabe 30}

Agnese, Pablo; Hromcová, Jana:

Low-Skill Offshoring: Labor Market Policies and Welfare Effects

http://fhdd.opus.hbz-nrw.de/volltexte/2014/858/

\section{Ausgabe 29}

Khabyuk, Olexiy:

Chancen einer deutsch-russischen wissenschaftlichen Zusammenarbeit am Beispiel der Medienökonomie http://fhdd.opus.hbz-nrw.de/volltexte/2014/854/ 


\section{Ausgabe 28}

Turban, Manfred:

Hybride Distributionssysteme auf Basis von Systemmarken bei vertikalen Unternehmen im Non-Food-

Konsumgütersektor und ihre Internationalisierung

http://fhdd.opus.hbz-nrw.de/volltexte/2014/853/

\section{Ausgabe 27}

Fischer, Peter C.:

Globalisierung und Recht: Auswirkungen der Globalisierung auf die Praxis grenzüberschreitender Transaktionen aus deutscher Perspektive

http://fhdd.opus.hbz-nrw.de/volltexte/2014/852/

\section{Ausgabe 26}

Albers, Felicitas G.:

Unternehmensziele und Compliance

http://fhdd.opus.hbz-nrw.de/volltexte/2014/851/

\section{Ausgabe 25}

Bleuel, Hans-H.:

Ökonomische Wechselkursrisiken: Relevanz, Bestimmung und Steuerung im russisch-deutschen

Geschäftsverkehr

http://fhdd.opus.hbz-nrw.de/volltexte/2014/850/

\section{Ausgabe 24}

Funk, Lothar:

Varianten von Marktwirtschaften: Lehren für Russland

http://fhdd.opus.hbz-nrw.de/volltexte/2014/856/

\section{Ausgabe 23}

Agnese, Pablo:

Offshoring and Productivity Revisited: A Time-Series Analysis

http://fhdd.opus.hbz-nrw.de/volltexte/2013/799/ 


\section{Ausgabe 22}

Ziehe, Nikola; Stevens, Sarah:

Erfolgreiche Interaktion mit Digital Natives im Social Commerce: Eine theoretische und explorative Analyse von Erfolgsfaktoren in der Kunden-Kunden-Kommunikation

http://fhdd.opus.hbz-nrw.de/volltexte/2012/754/

\section{Ausgabe 21}

Kalka, Regine; Schmidt, Katharina Juliana:

Identitätsorientierte Markenführung im Dienstleistungsbereich am Beispiel der Versicherungsbranche: Eine explorative Studie

http://fhdd.opus.hbz-nrw.de/volltexte/2012/721/

\section{Ausgabe 20}

Weinert, Stephan:

Diversity der DAX30-Vorstände: Anspruch und Wirklichkeit

http://fhdd.opus.hbz-nrw.de/volltexte/2012/718/

\section{Ausgabe 19}

Pagel, Sven; Jürgens, Alexander; Günther, Janina; Mollekopf, Katrin:

Kommunikationscontrolling von Digital Signage : Wahrnehmung, Nutzung und Wirkung von Point-of-Sale-

Bildschirmmedien

http://fhdd.opus.hbz-nrw.de/volltexte/2011/666/

\section{Ausgabe 18}

Kalka, Regine; Lux, Dorothee:

Bedeutung, Ansätze und organisatorische Verankerungen von Employer und Behavioral Branding in Unternehmen: Eine explorative empirische Untersuchung

http://fhdd.opus.hbz-nrw.de/volltexte/2011/661/

\section{Ausgabe 17}

Ziehe, Nikola; Stoll, Raina:

Die Wirkung von Kundenbindungsmaßnahmen auf das Einkaufsverhalten im Einzelhandel: Treueprogramme versus Kundenkarten im deutschen Lebensmitteleinzelhandel

http://fhdd.opus.hbz-nrw.de/volltexte/2011/658/ 


\section{Ausgabe 16}

Pagel, Sven; Goldstein, Sebastian; Janßen, Bernd; Sadrieh, Karim:

Angebot und Nutzung von Videos in Online-Shops: Ein Forschungsprogramm zur multimedialen

Bewegtbildkommunikation im Electronic Commerce

http://fhdd.opus.hbz-nrw.de/volltexte/2010/655/

\section{Ausgabe 15}

Funk, Lothar:

Die europäische Flexicurity-Strategie: Ein Überblick zu wichtigen Vor- und Nachteilen

http://fhdd.opus.hbz-nrw.de/volltexte/2010/653/

\section{Ausgabe 14}

Pagel, Sven; Jürgens, Alexander:

Video-Content auf Youtube-Kanälen von TV-Sendern am Beispiel von ARD, BBC und Deutsche Welle:

Wahrnehmung, Nutzung und Wirkung von redaktionellen Video-Inhalten

http://fhdd.opus.hbz-nrw.de/volltexte/2010/652/

\section{Ausgabe 13}

Nicodemus, Gerd:

The Option Value of Investments in Energy-Efficient and Renewable Energy Technologies

http://fhdd.opus.hbz-nrw.de/volltexte/2010/647/

\section{Ausgabe 12}

Turban, Manfred:

Markenfokussierte Distributionssysteme in Non-Food-Konsumgüterbranchen: Strukturmerkmale, Typisierungsansatz und Steuerungsproblematik

http://fhdd.opus.hbz-nrw.de/volltexte/2009/587/

\section{Ausgabe 11}

Pagel, Sven; Goldstein, Sebastian:

Nutzung und Wirkung von Video-Content in Online-Jobbörsen: Erkenntnisse einer explorativen Studie http://fhdd.opus.hbz-nrw.de/volltexte/2009/531/

\section{Ausgabe 10}

Albers, Felicitas; Pagel, Sven; Peters, Horst:

Wahrnehmung und Image der Rheinbahn AG im Bewusstsein der Öffentlichkeit

http://fhdd.opus.hbz-nrw.de/volltexte/2009/530/ 


\section{Ausgabe 9}

Gerhards, Claudia:

Branded Entertainment im TV: Ein Bestimmungsversuch aus Sicht der Systemtheorie und der Prinzipal-AgentTheorie und Handlungsempfehlungen für das Schnittstellenmanagement

http://fhdd.opus.hbz-nrw.de/volltexte/2009/518/

\section{Ausgabe 8}

Bleuel, Hans-H.:

The German Banking System and the Global Financial Crisis: Causes, Developments and Policy Responses http://fhdd.opus.hbz-nrw.de/volltexte/2009/511/

\section{Ausgabe 7}

Kalka, Regine; Krähling, Sabrina:

Multimediale Public Relations bei Messegesellschaften

http://fhdd.opus.hbz-nrw.de/volltexte/2009/509/

\section{Ausgabe 6}

Albers, Felicitas:

Compliance der Compliance: Elektronische Analyseverfahren personenbezogener Daten zur Prävention und Aufdeckung geschäftsschädigender Handlungen in Unternehmen. Diskurs aus Anlass des sogenannten ,Datenskandals' der Deutsche Bahn AG

http://fhdd.opus.hbz-nrw.de/volltexte/2009/508/

\section{Ausgabe 5}

Markowski, N.; Grosser, K.; Kuhl, R.:

Analyse von Barrieren und Hemmnissen beim Wissenstransfer zwischen Hochschulen und KMU http://fhdd.opus.hbz-nrw.de/volltexte/2008/493/

\section{Ausgabe 4}

Quack, Helmut:

Der Einsatz der multidimensionalen Skalierung (MDS) im nationalen und internationalen Marketing;

Teil 1: Mathematische, empirische und auswertungsbezogene Vorgehensweise

http://fhdd.opus.hbz-nrw.de/volltexte/2008/486/

\section{Ausgabe 3}

Turban, Manfred; Wolf, Julia:

Absatzbezogene Strategien der Internationalisierung des Lebensmittel-Discountmarkts bei Aldi und Lidl im Vergleich

http://fhdd.opus.hbz-nrw.de/frontdoor.php?source opus=475 


\section{Ausgabe 2}

Bleuel, Hans-H.:

Ein Analyseraster zur Bestimmung langfristiger Wechselkursrisiken von Unternehmen - dargestellt am Beispiel der US-Dollar-Abwertung

http://fhdd.opus.hbz-nrw.de/volltexte/2008/439/

\section{Ausgabe 1}

Turban, Manfred:

Kosten- und Leistungsstrukturen ausgewählter Betriebstypen des Lebensmittel-Ladeneinzelhandels in Deutschland im Vergleich

http://fhdd.opus.hbz-nrw.de/frontdoor.php?source opus=414 


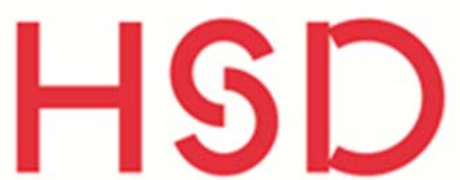

Hochschule Düsseldorf

University of Applied Sciences

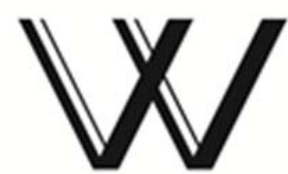

Fachbereich

Wirtschaftswissenschaften

Faculty of

Business Studies
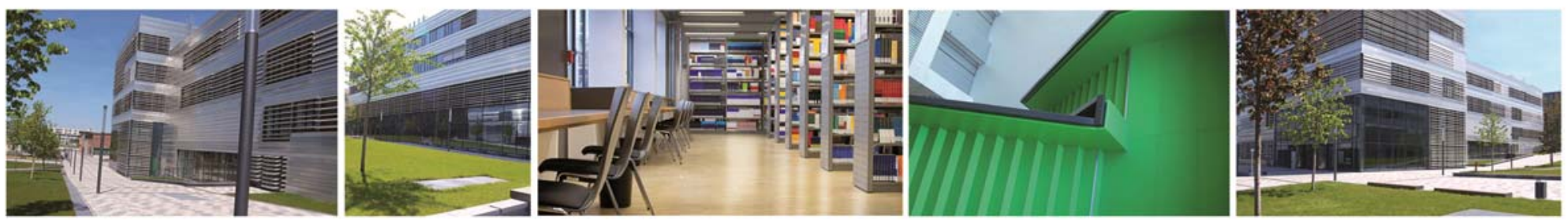

Düsseldorf Working Papers in Applied Management and Economics 